\title{
Ear Abuse among School Children in Ekiti, Nigeria
}

\author{
Toye Gabriel Olajide ${ }^{* 1}$, Oyebanji Anthony Olajuyin ${ }^{2}$, Adebisi Paul Eletta ${ }^{3}$, Adepeju Oluwatona Dosunmu ${ }^{4}$ \\ ${ }^{1,4}$ Department of Ear, Nose and Throat, Federal Teaching Hospital, Ido Ekiti/ Afe Babalola University, \\ Ado Ekiti (ABUAD), Nigeria \\ ${ }^{2}$ Department of Ear, Nose and Throat, Ekiti State University Teaching Hospital, Ado Ekiti, Nigeria. \\ ${ }^{3}$ Department of Ear, Nose and Throat, Federal Medical Centre, Bida, Nigeria \\ E-mail: 'toyeolajide@yahoo.co.uk, ${ }^{2}$ oyebanjiolajuyin@yahoo.com, ${ }^{3}$ elettaadebisi@yahoo.com, ${ }^{4}$ pejudosunmu@gmail.com
}

\section{Corresponding Author:}

\author{
Dr Toye Gabriel Olajide
}

Federal Teaching Hospital, Ido Ekiti / Afe Babalola University, Ado Ekiti, Nigeria

Tel: +2348034656993

\begin{abstract}
Background/Aim: Otological trauma due to physical abuse is a common occurrence among the young persons. However, the condition is overlooked and underreported. This study aimed at determines prevalence and profile of ear abuse in school children in Ekiti, Nigeria. Methodology: This study was a cross sectional survey among secondary school students in Ekiti, South Western Nigeria. Data were collected using a semi-structured interviewer administered questionnaire. Results: A total of 130 students aged 13 and 16 years participated in the survey. Of the 130 students that were interviewed, $76(58.5 \%)$ had been otologically abused (Slapped) at one time or the other. Majority (26.9\%) of the students were slapped by their parents. Left ear was mostly affected in $39(51.3 \%)$ of them. The most common reason for the slap was disobedience in $56(73.7 \%)$ of the students. Only 5.4\% reported the case of slap to appropriate authority. About $73.7 \%$ did not receive treatment or any form of intervention. Pure tone audiogram (PTA) done showed that $32.9 \%$ (19.7\% male and $13.2 \%$ female) of the respondents had mild conductive hearing loss. Conclusion: Ear abuse, although poorly recognized and underreported is still common in our society. A prevalence of $58.4 \%$ with $32.9 \%$ hearing loss was recorded in this study. There is need for a public enlightenment programs in order to create awareness among teachers, school managers and parents so as to address these ugly trends and to prevent late sequel of hearing loss and learning disability.
\end{abstract}

Keywords: Ear abuse, school children, hearing loss, Nigeria.

\section{Introduction}

Physical abuse which is a form of child abuse is any intentional act causing injury or trauma to another person by way of bodily contact. In most cases, children are the victims of physical abuse, but adults can also be victims, as in cases of domestic violence or workplace aggression. ${ }^{[1]}$ Physical abuse can be inform of punching, beating, kicking, biting, burning or otherwise harming a child. ${ }^{[2]}$ It is most visible form of child maltreatment. Specifically in the ear, such physical abuse may come by way of slapping, biting, grabbing, pulling or twisting of pinna. Many times, physical abuse results from inappropriate or excessive physical discipline. It is common in both developing and developed world. World health organization (WHO) had also reported many cases in Arab countries in the recent times. ${ }^{[3]}$ However a look at the society shows that child abuse occurs not only at home but has found its way into the school system thus constituting a barrier to the attainment of sound educational development in the country. ${ }^{[4]} \mathrm{A}$ parent or caretaker and teachers in the schools in anger may be unaware of the magnitude of force with which he or she strikes the child. These are substantial barriers to identification of child abuse, which will not be detected unless specifically asked for it. There is need to differentiate between abuse and corporal punishment. Many children are abused daily under the guise of punishment. Any punishment or correction that threatens the life, health or wellbeing of a child is an abuse. ${ }^{[5]}$ Corporal punishment on the other hand is the use of physical force with the intention of causing bodily pain, but not injury for the purpose of correction or control. $^{[6,7]}$ Factors that can contribute to child abuse include parents' immaturity, lack of parenting skills, poor childhood experiences and social isolation, as well as frequent crisis situations, drug or alcohol problems and domestic violence. ${ }^{[8]}$ Kellogg et al mentioned that child abuse is as a result of set of interrelated familial, social, psychological and economic variables. ${ }^{[9]}$ Generally, factors that can influence an individual's susceptibility to child abuse are age, gender, misuse of alcohol, low self-worth, lack of self-control when upset or angry, hyperactivity and impulsivity of child, neighbourhoods, workplaces, schools and traditional norms that support the physical punishment of children. ${ }^{[10-14]}$ Early Consequences of child abuse as related to ear trauma are otalgia, bruises, laceration, tympanic membrane perforation, infections and there may be late sequel of hearing loss and learning disability. Hanigan et al reported bilateral auricular hematomas, recurrent tympanic membrane lacerations and tin ear 
syndrome which consist of triad of signs of bruising of the ear, retinal hemorrhages and cerebral edema. ${ }^{[15]}$

Apart from physical abuse, other forms of child abuse are emotional abuse, sexual abuse, neglect and child exploitation (child labour) ${ }^{[4,16]}$ It is important to know that child sexual abuse, child labour and child neglect are more often re- ported than physical abuse in form of corporal punishment. ${ }^{[17-20]}$ There is dearth of data on prevalence and incidence of child physical abuse in Nigeria. There has been no study on child ear abuse and its sequelae in our locality. The aim of this study therefore was to determine the prevalence and profile of ear abuse among school children in Ekiti.

\section{Methodology}

It is a cross sectional descriptive study carried out among secondary school students (JS 3 and SS 3) in Ikere Ekiti, South Western, Nigeria. It was carried out between January, 2015 and April, 2015. A written request was made to the school authority seeking official permission prior to the study. Simple random sampling technique was used to select the classes that were used for the study. Those students that gave consent had direct questioning using a pre tested semi-structured interviewer administered questionnaire by an ENT specialist in the absence of their teachers and parents. All the participants were fully briefed and informed about the core and purpose of the research and hence their consent was obtained. They were assured of the confidentiality of the data collected. Participants were asked not to write any information that may enable them to be identified. All the students that participated had otological examination. Those that had wax were removed. Turning fork tests and pure tone audiometry assessment of hearing done as and when necessary. The study was conducted in a very familiar, quiet and safe environment for the students within the school compound. Ethical clearance was obtained from our institution. Data obtained were entered and analyzed using the Statistical Package for the Social Sciences (IBM SPSS 20.0) and the results were expressed in simple tables and charts.

\section{Results}

One hundred and thirty (130) students completed our questionnaires and were fully screened. Their age ranged from 13 years to 16 years with a mean of $14.45 \pm 1.01 \mathrm{SD}$. There are 49 $(37.7 \%)$ males and $81(62.3 \%)$ females given a male to female ratio of $1: 1.7$. Table 1 .

Table 1: Showing demographic characteristics of the respondents

\begin{tabular}{|l|c|c|}
\hline \multicolumn{1}{|c|}{ Variable } & $\begin{array}{c}\text { Frequency } \\
(\mathbf{N})\end{array}$ & $\begin{array}{c}\text { Percentage } \\
(\mathbf{\%})\end{array}$ \\
\hline Age (Years) $(\mathbf{n = 1 3 0})$ & & \\
13 Years & 28 & 21.5 \\
14 Years & 36 & 27.7 \\
15 Years & 45 & 34.6 \\
16 Years & 21 & 16.2 \\
Gender /sex $(\mathbf{n = 1 3 0 )}$ & & \\
Male & 49 & 37.7 \\
Female & 81 & 62.3 \\
\hline
\end{tabular}

\begin{tabular}{|l|c|c|}
\hline Slapped (n=130) & 76 & 58.5 \\
Yes & 54 & 41.5 \\
No & & \\
Sources of slap (n=76) & 35 & 26.9 \\
Parents & 20 & 15.4 \\
Brothers/Sisters & 10 & 7.7 \\
Teachers & 5 & 3.8 \\
Friends/mates & 2 & 1.5 \\
Seniors in the school & 4 & 3.1 \\
Multiple sources & & \\
Received treatment (n=76) & 56 & 73.7 \\
No treatment & 17 & 22.4 \\
Treated at & 3 & 3.9 \\
Treated in the hospital & & \\
Report to higher authority & 7 & 5.4 \\
(n=76) & 69 & 94.6 \\
Yes & & \\
No & & \\
Can slap cause damage to & & \\
ear (n=130) & 112 & \\
Yes & 6.2 & \\
No & & \\
Not sure & & \\
\hline & & \\
Ofi & & \\
\hline
\end{tabular}

Of the 130 respondents, $76(58.5 \%)$ had been slapped at one time or the other given a prevalence of $58.4 \%$. Figure 1 .

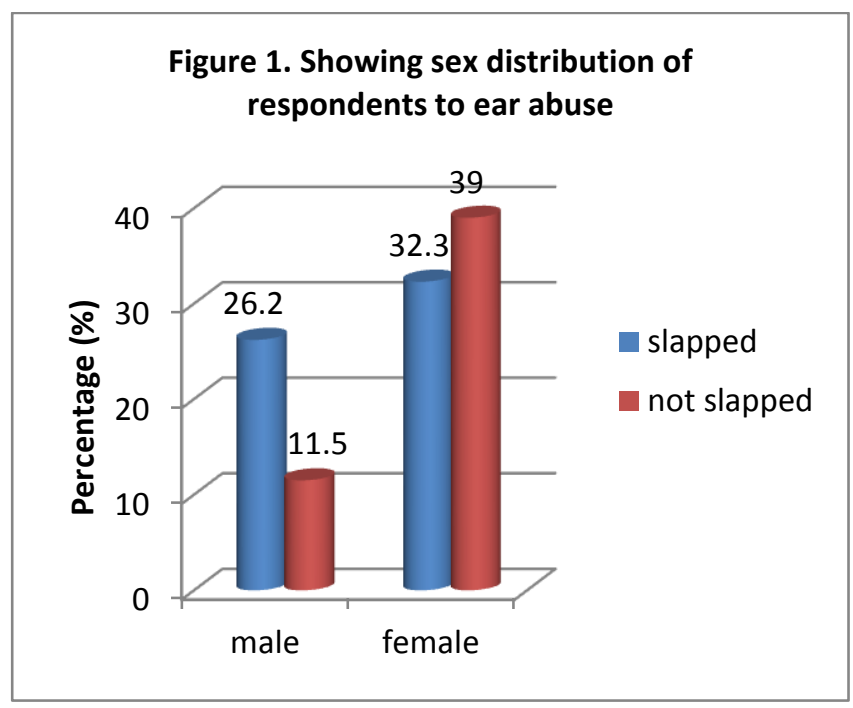

Majority $(26.9 \%)$ of the students were slapped by their parents, $15.4 \%$ by brothers/sisters, $7.7 \%$ by their teachers, $3.8 \%$ by their friends/mates, $3.1 \%$ were from different sources while $1.5 \%$ were by their seniors in the school. Table 1.

Of the 76 respondents that was slapped, left ear was mostly affected in $39(51.3 \%)$, followed by both ears in $24(31.6 \%)$ and $13(17.1 \%)$ affected the right ear. Figure 2 
International Journal of Innovative Research in Medical Science (IJIRMS)

Volume 03 Issue 12 Dec 2018, ISSN: 2455-8737, Imp. Factor - 4.102

Available online at - $\underline{w w w . j j i r m s . i n}$

Figure 2. Showing affected ear

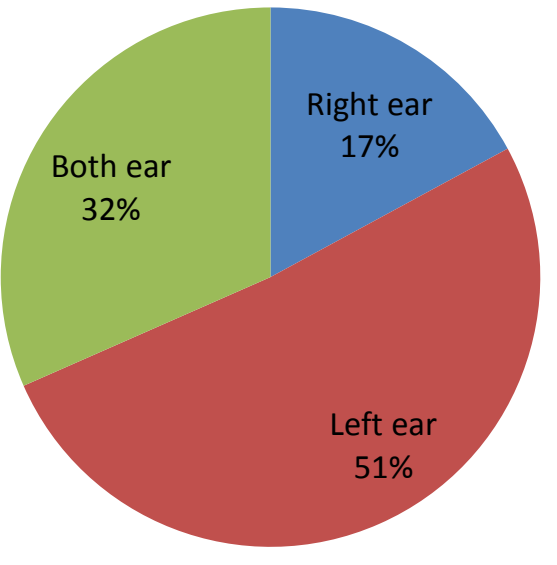

Reasons for the physical abuse (slap) were disobedience in $56(73.7 \%)$, fighting/argument/separating a fight in $8(10.5 \%)$, lateness to school in $5(6.6 \%)$, multiple offences at different time in
$4(5.3 \%)$, stealing in $1(1.3 \%)$ and absenteeism at the school fellowship in $2(2.6 \%)$. Table 2.

Table 2: Showing reasons why respondents were slapped

\begin{tabular}{|l|c|c|}
\hline Reasons & $\begin{array}{c}\text { Frequency } \\
(\mathbf{N})\end{array}$ & $\begin{array}{c}\text { Percentage } \\
(\mathbf{\%})\end{array}$ \\
\hline Disobedience & 56 & 73.7 \\
Fighting/argument & 8 & 10.5 \\
Lateness to school & 5 & 6.6 \\
Multiple offences & 4 & 5.3 \\
Stealing & 1 & 1.3 \\
Absent from fellowship & 2 & 2.6 \\
\hline Total & $\mathbf{7 6}$ & $\mathbf{1 0 0}$ \\
\hline
\end{tabular}

The immediate problems or symptoms noticed by the respondents after the slap are noisy sensation in the ear in $38(50.0 \%)$, ear ache in $24(31.6 \%)$, diminished hearing in $5(6.6 \%)$ students, headache in $3(4.0 \%)$, while tearing and redness of eye , fainting/dizziness , and bleeding were noticed in $2(2.6 \%)$ of the students each. Figure 3

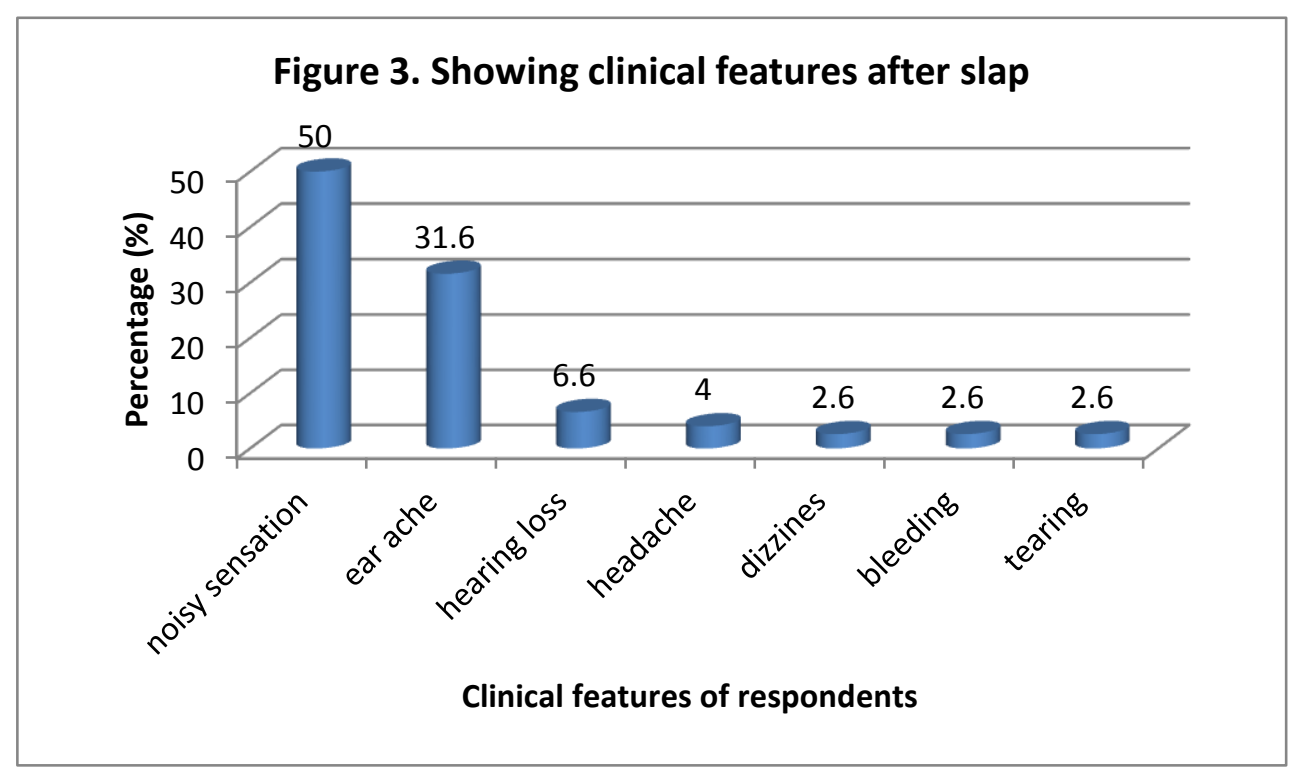

About $73.7 \%$ of our respondents did not receive treatment or any form of intervention, $22.4 \%$ received treatment at home while 3.9 $\%$ went to hospital. Only $5.4 \%$ reported the case of slap while $94.6 \%$ did not. About $86.2 \%$ of the students believed that physical abuse like slapping can cause damage to ear, 9.2\% did not believe while $4.6 \%$ were not sure. Table 1. Pure tone audiogram done showed that $19.7 \%$ of male respondents had mild conductive hearing loss as compared to $13.2 \%$ female respondents. Figure 4

Figure 4. Sex of respondents that was slapped and hearing loss

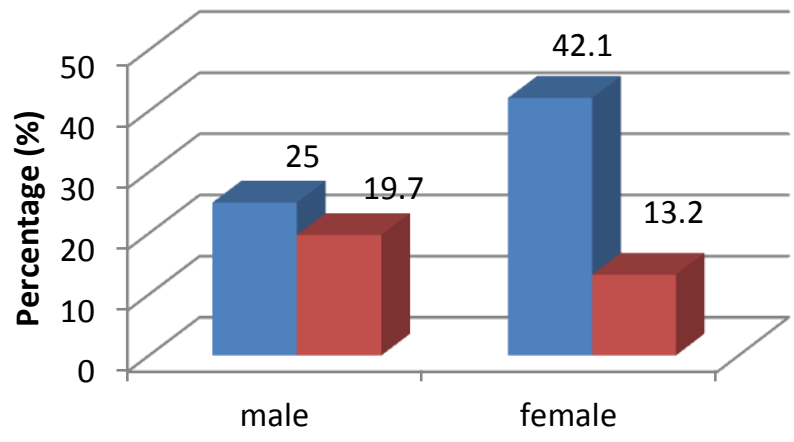

Normal hearing

Mild hearing loss

Sex of respondents 


\section{International Journal of Innovative Research in Medical Science (IJIRMS) Volume 03 Issue 12 Dec 2018, ISSN: 2455-8737, Imp. Factor - 4.102 Available online at - www.ijirms.in}

\section{Discussion}

Violence is a daily occurrence among almost every young person in the world today. In general child physical abuse and neglect are common in Nigeria, yet poorly reported. ${ }^{[21]}$ In this study a prevalent rate of child ear abuse of $58.4 \%$ was recorded. This showed that ear abuse which is a form of physical punishment is still rampant in the society especially in Nigeria where corporal punishment is being held in high esteem as a way of correcting and instilling discipline in young children. Also in this study, majority of our respondents were otologically abused (slapped) by their parents including relations. This might have been favoured by the traditional norms that support the physical punishment of children in our environment. Teachers in the schools were not left out of this scenario as $7.7 \%$ of the students were slapped by their teachers in our study. Child abuse is not limited to homes; there is also abuse in the school and other institutions. ${ }^{[22-24]}$ Children are subject to physical punishment from their teachers for committing minor offences like coming to school late or failure to do homework and for other major offences like fighting and insulting others. ${ }^{[4]}$ Physical abuse is one form of abuse that persistently occurs in schools especially in the form of correction or corporal punishment. Even though spanking is culturally approved for correcting children most times the teachers do this in anger and in the process the child is left injured and physically inflicted with bruises and pains. ${ }^{[6]}$ Often, teachers encourage senior students to prey on younger and weaker students, victimizing them in the process, thereby building and encouraging the culture of violence as senior students are empowered to get physical and discipline their junior ones by engaging in corporal punishment. ${ }^{[5]}$ This is similar to our findings in this study where some of our respondents were slapped by their senior's students as to instill discipline as a form of corporal punishment. In recent times, the use of more positive forms of behavior modification is advocated such as persuasion, appeal to reason and good judgment plus the reward for desirable forms of behavior. ${ }^{[6]}$ Majority of the slaps were leftsided. This may be due to the fact that majority of the culprits were right-handed and were facing the victims while the right-sided slaps may be due to slapping from behind the victim or that the culprits were left handed. This has a medico-legal implication if the case is reported to the concerned authority.

Large percentage of respondents in this study was slapped because of disobedience. The disobedience was to their parents, brothers/ sisters at home, teachers and their seniors in the school. Few of them were slapped severally due to multiple offences. Many of the students did not report the incident to the concerned authority. Their failure to report to the concerned authority was due to guilty conscience; they are afraid of reporting their parents, brothers, teachers and seniors to higher authority when in their own opinion they were guilty of their offence. Lack of effective structures for reporting of physical abuse of children together with socio-cultural belief may also have accounted for this. ${ }^{[21]}$ Also, some of them did not experience any symptom immediately after the slap; hence they did not take it serious. For those who perceived symptoms after the slap, the major clinical features noticed (by the students after the slap) were noisy sensations in their ears, ear ache, hearing loss and headache. Large number of students did not seek any form of treatment or intervention since there was no immediate effect. Some were treated at home. Only $2.3 \%$ of the victims received treatment in the hospital. Probably because of severity of physical injury or their parents may feel serious concern when such students make reports. The implication of this is that majority of them may present with medical problem later as sequel to the slap they have received. About $86.2 \%$ of the respondents believed that slap to the ear are very dangerous.

In this study, $19.7 \%$ of male respondents have conductive hearing loss when compared to $13.2 \%$ in females in mild category. Rathore et al in their study also recorded hearing loss to be more in males than females although he got a higher figure of $72.4 \%$ and $45.1 \%$ respectively for mild category. ${ }^{[26]}$ None of the victims were found with tympanic membrane perforation on examination. The reason for this may be that the perforation has healed at the time of this study. As noted by workers, spontaneous resolution is the rule in tympanic membrane perforation following hands slap. Although the number of females that was slapped was more than their males, the findings in our study might have been due to the extent or frequency of impact inflicted on our respondents. Males appear more stubborn and tend to disobey their parents or teachers or seniors than females. Other reasons for male preponderance as reported by other authors are due to our social system where females stay in-door and males go out more often and are involved in education and swimming etc. ${ }^{[27]}$ Generally it is pertinent to observe that there are no strong guidelines or laid down policies, regarding corporal punishment and children, like it is done in developed countries. This might have encouraged the flagrant abuse of children in African traditional societies 5. Although, we did not investigate the effect of the ear abuse on the educational performance, it may be worthwhile to conduct empirical study in this regard in future.

\section{Conclusion}

Child ear abuse, although poorly recognized and underreported is still common in our society. A prevalence of $58.4 \%$ with $32.9 \%$ hearing loss was recorded in this study. Most of the culprits of physical abuses were parents/relatives and school teachers. There is need for public enlightenment programs in order to create awareness among teachers, school managers and parents so as to address these ugly trends and to prevent late sequel of hearing loss and learning disability.

Conflict of interest: Nil

Financial Support: Nil

References

[1] Physical abuse. https://en.wikipedia.org/wiki/Physical_abuse Assessed on $20 / 11 / 2018$

[2] Eliminating corporal punishment in schools. National Commission for Protection of Child Rights (NCPCR) https://www.researchgate.net/...school...corporal_punish ment/.../Eliminating+Corporal Assessed on 20/11/2018

[3] World health organization (WHO). International society for the prevention of child abuse and neglect (ISPCAN). Preventing child maltreatment: a guide to taking action and generating evidence. Geneva: World Health Organization; 2006. 


\section{International Journal of Innovative Research in Medical Science (IJIRMS) Volume 03 Issue 12 Dec 2018, ISSN: 2455-8737, Imp. Factor - 4.102 Available online at - $\underline{w w w . j j i r m s . i n}$}

[4] Umobong ME. Child Abuse and its Implications for the Educational Sector in Nigeria. $106-118$. Assessed on 25/11/2018.

[5] Ojeme V. Child abuse: sign of a dysfunctional society. Vanguard newspaper 21/9/2017. Assessed online $6 / 12 / 2018$.

[6] Straus MA. Beating the devil out of them: Corporal punishment in American families and its effects on children. New Hampshire: Lexington Books.; 1994.

[7] Committee on the Rights of the Child General Comment No. 8 on "The right of the child to protection from corporal punishment and other cruel or degrading forms of punishment (arts. 19; 28, para. 2; and 37, interalia)", para. 11; 2006.

[8] Child

Abuse:

http://www.americanhumane.org/children/stop-childabuse/fact-sheets/child-physical-abuse.html. Assessed on 2/12/2018

[9] Kellogg, N. D., Parra, J. M., \& Menard, S. (2007). Children with anogenital symptoms and signs referred for sexual abuse evaluations. Arch Pediatric Adolescent Medical, 152, 634-641.

[10] Dube, S. R., Anda, R. F., Whitfield, C. L., Brown, D. W., Felitti, V. J., Dong, M., \& Giles, W. H. (2005). Longterm consequences of childhood sexual abuse by gender of victim. American Journal of Preventive Medicine, 28, 430-438.

[11] Hopper, J. (1998). Child sexual abuse: Statistics, research, resources. Boston, MA: Boston University School of Medicine

[12] World health organization (WHO). (2002). World report on violence and health. Geneva: World Health Organization.

[13] Belsky, J. (1980). Child maltreatment: An ecological integration. American Psychologist, 35, 320-335.

[14] Belsky, J. (1993). Etiology of child maltreatment: A developmental ecological analysis. Psychological Bulletin, 114, 413-434.

[15] Hanigan WC, Peterson RA, Njus G. Tin ear syndrome: rotational acceleration in pediatric head injuries. Pediatrics 1987; 80:618-22. Aschoor A. Hearing level of school children in Daman. J L O 1983; 97:37-41.

[16] Sakelliadis, E. I., Spiliopoulou, C. A., \& Papadodima, S. A. (2009). Forensic investigation of child victim with sexual abuse.Indian Pediatric, 46, 144-151
[17] Audu, B., Geidam, A. and Jarma, H. (2009) Child labour and sexual assault among girls in Maiduguri, Nigeria. International Journal of Gynacology and Obstetrics, 104, 64-67. http://dx.doi.org/10.1016/j.ijgo.2008.09.007

[18] Obisesan, K.A., Adeyemo, A.A. and Onifade, R.A. (1999) Childhood sexuality and child sexual abuse in South West Nigeria. Journal of Obstetrics \& Gynecology, 19, 624-626. http://dx.doi.org/10.1080/01443619963897

[19] Omorodion, F.J. (1994) Child sexual abuse in Benin City, Edo state Nigeria: A sociological analysis. Issues Com- prehensive Pediatric Nursing, 17, 29-36. http://dx.doi.org/10.3109/01460869409078286

[20] Wilson-Oyelaran, E.B. (1989) The ecological model and study of child abuse in Nigeria. Child Abuse \& Neglect, 13, 379-387. http://dx.doi.org/10.1016/01452134(89)90078-1

[21] Uzodimma CC*, Ogundeyi MM, Dedeke FI, Owolabi O. Child maltreatment, abuse and neglect in a Nigerian adolescent boy, the common but unheard menace: A case report from South west, Nigeria. Open Journal of Pediatrics. (OJPed) 2013; 3: 377-380. http://dx.doi.org/10.4236/ojped.2013.34068 Published Online December 2013 (http://www.scirp.org/journal/ojped/)

[22] Wilson, E.B. and Afamefuna, G.C. (1986) Child abuse in institutions: The case of day care centres in Nigeria. Child Abuse \& Neglect, 10, 93-98. http://dx.doi.org/10.1016/0145-2134(86)90037-2

[23] (2013) World report on violence and health. http://www.who.int/violence_injury_prevention/violence /global_campaign/en/chap3.pdf

[24] Chianu, E. (2000) Two deaths, one blind eye, one imprisonment: Child abuse in the guise of corporal punishment in Nigeria schools. Child Abuse \& Neglect, 24, 1005- 1009. http://dx.doi.org/10.1016/S0145-2134 (00)00154-X.

[25] Rathore PK, Raj A, Mandal S, Meher R, Girhotra M. EAR ABUSE IN SCHOOL CHILDREN. Indian Journal of Otolaryngology and Head and Neck Surgery. 2006; 58, (1): $61-62$.

[26] Tuli BS, Parmar TL. Incidence of deafness in school going children. Indian J Otol 1988; 40:137.

[27] Sharma H, Bhusan V, Dayal D. Preliminary study of hearing handicap in school going children. Indian $\mathrm{J}$ Laryngol Otol Head Neck Surg 1992; 1:119-24. 